\title{
Planktonic bioluminescence measurements in the frontal zone of Almeria-Oran (Mediterranean Sea)
}

\author{
Anne-Sophie CUSSATLEGRAS ${ }^{a}$, Patrick GEISTDOERFER ${ }^{\mathrm{a}}$, Louis PRIEUR ${ }^{\mathrm{b}}$ \\ a IRÉNAV, École navale, BP 600 Lanvéoc-Poulmic, 29240 Brest naval, France \\ ${ }^{\mathrm{b}}$ Laboratoire de physique et chimie marines, Observatoire de Villefranche-sur-mer, BP08, 06230 Villefranche- \\ sur-mer, France
}

Received 7 August 2000; revised 15 January 2001; accepted 18 January 2001

\begin{abstract}
Plankton bioluminescence measurements were made in the Almeria-Oran frontal zone during December 1997 and January 1998. Vertical profiles of bioluminescence, chlorophyll fluorescence, temperature and salinity were obtained using a bathyphotometer associated with a CTD (conductivity-temperature-depth) probe on a rosette. The first leg of the cruise was a regular sampling along a cross section of the area. The second leg consisted of a repetitive sampling of twelve stations at each one of the eight sites located in different water masses. Hydrological data allowed a distinction from north to south of three different water masses: Mediterranean, frontal and Atlantic. The continuous sampling indicated an increased bioluminescence in the frontal zone, with high values in the surface water and numerous light emissions as deep as $200 \mathrm{~m}$. Mediterranean waters are characterized by an intense bioluminescence in the first $50 \mathrm{~m}$ with a maximum just above the thermocline and a few bioluminescent flashes above, whereas bioluminescence in Atlantic waters is evenly distributed from the surface to $130 \mathrm{~m}$ depth with no strong maxima. Inter-site bioluminescence variability is much greater than intra-site, demonstrating that bioluminescence profiles clearly reflect differences between hydrological areas. Bioluminescence is correlated with fluorescence at three out of the eight sites, suggesting a relative importance of chlorophyllian bioluminescent organisms. No direct correlation with temperature and salinity has been demonstrated, however, the thermocline is nearly always accompanied by an increased bioluminescent activity. (C) 2001 Ifremer/CNRS/IRD/Éditions scientifiques et médicales Elsevier SAS
\end{abstract}

Résumé - Mesures de bioluminescence planctonique dans la zone du front Alméria-Oran (Méditerranée). Des mesures de bioluminescence planctonique ont été réalisées dans la zone du front Almeria-Oran en décembre 1997 et en janvier 1998. Des profils verticaux de bioluminescence, de fluorescence de la chlorophylle, de température et de salinité ont été obtenus avec un bathyphotomètre couplé à une sonde CTD (conductivity-temperature-depth) et à un fluorimètre. La première partie de la mission consistait en un échantillonnage régulier le long d'une radiale transversale au front. Au cours de la seconde partie, un échantillonnage répétitif de douze stations sur huit sites correspondant à différentes masses d'eau caractéristiques de la zone frontale a été effectué. Les données hydrologiques permettent de distinguer trois aires marines du nord au sud: «méditerranéenne», frontale et «atlantique». L'échantillonnage en continu indique une augmentation de la bioluminescence dans la zone frontale, avec de fortes valeurs en surface et de nombreuses émissions lumineuses jusqu'à $200 \mathrm{~m}$ de profondeur. Les eaux méditerranéennes sont caractérisées par une stratification de la bioluminescence qui présente des valeurs intenses dans les 50 premiers mètres et maximales juste au dessus de la thermocline, tandis que la bioluminescence des eaux atlantiques est régulièrement distribuée dans la couche de mélange,

*Correspondence and reprints: fax: +33298233857.

E-mail addresses: cussat@ecole-navale.fr (A.S. CUSSATLEGRAS), geist@ecole-navale.fr (P. GEISTDOERFER), prieur@ccrv.obs-vlfr.fr (L. PRIEUR). 
entre la surface et $130 \mathrm{~m}$ de profondeur. Les profils de bioluminescence indiquent une variabilité inter-sites supérieure à la variabilité intra-sites et reflètent les différences de structures hydrologiques entre les sites. La bioluminescence et la fluorescence sont corrélées à trois des huit sites, suggérant une relative importance d'organismes chlorophylliens bioluminescents. Aucune corrélation directe entre la bioluminescence et la température ou la salinité n'a été mise en évidence, mais la thermocline est, dans de nombreux cas, accompagnée d'une augmentation de l'activité lumineuse. (C) 2001 Ifremer/CNRS/IRD/Éditions scientifiques et médicales Elsevier SAS

\section{frontal zone / Alboran Sea / bioluminescent plankton}

\section{zone frontale / mer d'Alboran / bioluminescence du plancton}

\section{INTRODUCTION}

Bioluminescence, a chemically based emission of visible light by living organisms, is common throughout the marine environment. Bioluminescent species are found among most types of organisms, ranging from bacteria to fish (Herring, 1978). In the epipelagic zone of the ocean, plankton organisms are the major light sources, with dinoflagellates, copepods, and euphausiids, being the most common (Tett and Kelly. 1973; Swift et al. 1983: Swift et al.. 1985b; Lapota et al.. 1989: Buskey. 1992. Swift et al. 1995). Measurements of in situ bioluminescence became more frequent in the past few years and concern many different part of the world's oceans. They all show great variations in space and time Batchelder ed bl, 1990: Lapota et al, 1994, 1995; Neilson et al, 1995)

Frontal zones are usually rich in terms of primary and secondary production Gould and Wiesenburg 1990. Lohrenz et al. 1988a, b). Different hypotheses have been proposed to explain this enrichment (Holligan. 1981. Eingree et al. 1975). In all cases, a higher production means more organisms of the first or of several trophic levels, and more particulate matter. As a result, higher levels of bioluminescence can be expected for more productive areas.

In the Strait of Gibraltar, the Atlantic surface water enters the Mediterranean Sea and flows in two anticyclonic eddies on both sides of the Isle of Alboran before it passes along the Algerian coast. The confrontation of the jet flow with the more saline Mediterranean water results in the formation of a geostrophic front, located approximately between Almeria (Spain) and Oran (Algeria). The Almeria-Oran frontal zone has been described since the 1970's CChenay. 1978: Chenay and Doblar. 1982: Tintore et al. 1988) and a first intensive study was made in
April-May 1991 during the Almofront-1 cruise Prieur et al. 1993: Prieur and Sournia. 1994b.

Hydrological fronts are characterized by strong horizontal density gradients (Sournia et al., 1990). Geostrophic fronts exhibit complex permanent hydrological structures essentially represented by two types of flow: the main current along the front (primary circulation) and a divergence-convergence movement across the jet (secondary circulation, Prieur and Sournia. 1994a). This cross frontal component usually promotes primary productivity in the surface waters and induces a subsequent downwelling of biomass (Videaس et_al, 1994).

Several studies have shown an increase of bioluminescence in particular hydrological structures such as upwelling Evstigneev and Cheripanov. 1997: Piontkovski et al. 1997) and thermal front Lapota and Losee, 1984; Lieherman et al. 1987: Losee et al. 1985). The particular area represented by the Almeria-Oran geostrophic front has never been studied before in terms of bioluminescence and this survey was an opportunity to collect a large amount of data about bioluminescence on a frontal zone. Because only dinoflagellates are bioluminescent in the phytoplankton, parallel observations of bioluminescence and chlorophyll distributions can provide information about population assemblages.

The aim of the present paper is to analyse the influence of a particular hydrological structure represented by a geostrophic front, on the distribution of bioluminescence and the relations with other physical and biological parameters. 


\section{MATERIAL AND METHODS}

\subsection{Study area}

In winter 1997-1998, the Almofront-2 cruise on board RV L'Atalante was divided into two legs (leg 1, Decem ber 1-21 and leg 2, January 2-25), representing two complementary sampling strategies. The first one consisted of a synoptic survey of the area using vesselmounted acoustic doppler current profiler (ADCP) continuous measurements and CTD (conductivitytemperature-depth) casts along a cross-frontal section. This section was visited twice at weekly intervals (stations 9-32 and 252-275, figure - dd). In addition, other sections were visited using the CTD Tow-Yo system and completed the overview of the area as seen on figure $l d$. For the leg 1, the jet and eddy system were stationary, as evidenced by the near surface currents. After the 2 nd of January, the eddy started and moved towards the W-NW along the Algerian coast, as seen by infrared images received on board and by the survey at the beginning of the second leg. Consequently, the start location of each site for $36 \mathrm{~h}$ of observation was determined after a short survey across the jet-eddy system. The location of each site was not predetermined as geographical coordinates, but as relative position in the jet-eddy system as shown in Ggure $1 \mathrm{~d}$. The strategy of the leg 2 consisted in investigating six sites across the virtual section, at similar positions to the CTD casts performed during leg 1 figure bb). Two other sites were also visited to look for changes along the jet meander. In order to find the virtual position inside the jet-eddy system, a depth of $1028 \mathrm{~kg} \mathrm{~m}^{-3}$ density isoline and the direction of horizontal currents were used. This density isoline changed from $30 \mathrm{~m}$ on the Mediterranean heavy waters down to $140 \mathrm{~m}$ inside the Atlantic water eddy. Such a change of depth was observed on CTD casts. The current intensity and direction helped to choose the virtual position of the jet meander. For instance, the current is northeastward before the crest, eastward at the crest and southward after the crest.

The drifters of the sediment trap line were generally parallel to the axis of the jet, except for sites 1 and 7 where a small drift towards the axis was also observed. Consequently, for these 2 sites, the depth of $1028 \mathrm{~kg} \mathrm{~m}^{-3}$ changed significantly in 2 days, this is the reason why sites 1 and 7 were separated into sites $1 \mathrm{a}, 1 \mathrm{~b}, 7 \mathrm{a}$ and $7 \mathrm{~b}$. It is noteworthy that these changes of position relative to the jet axis do not correspond to a long distance (not more than $5 \mathrm{~km}$ ) for these 2 sites. However, due to the strong gradient in the jet meander, this weak drift was sufficient to make significant changes in biological and physical parameters. The 8 sites were studied in detail during the second leg by performing about 12 consecutive hydrological casts in a $24 \mathrm{~h}$ period. A site was defined as a set of stations performed during the drift of a sediment trap line.

A total of 44 profiles $(0-1000 \mathrm{~m})$ along the cross section were obtained during the first leg of the cruise. During the second leg, the 8 sites were sampled with a total of 96 vertical profiles made between the surface and $1000 \mathrm{~m}$, except for 1 station per site at which the bathyphotometer was lowered to a depth of $2500 \mathrm{~m}$.

\subsection{Measurements}

Vertical profiling was carried out with a Sea-Bird SBE 9 (CTD with a Chelsea fluorometer and a bathyphotometer for bioluminescence measurements).

The bathyphotometer, built at the Naval Academy, (figure 日) is comprised of a dark chamber $(12 \mathrm{~mL})$ separated by a glass window from a photomultiplier tube that can detect light intensities from $10^{-4}$ to $10^{-9} \mu \mathrm{W} \mathrm{cm} \mathrm{cm}^{-2}$. The spectral range for detection is $450 \mathrm{~nm}$ to $550 \mathrm{~nm}$, corresponding to the blue-green bioluminescent light emitted by the living organisms. A pump set at a constant flow rate $\left(0.4 \mathrm{~L} \mathrm{~s}^{-1}\right)$ ensures the incoming flow of seawater in the dark chamber. A grid at the entrance of the chamber provokes a turbulent flow, giving a mechanical and synchronous stimulation of the organisms entering it. Organisms bigger than $1 \mathrm{~mm}$ are filtered by the grid (1 $\mathrm{mm}$ mesh). Bioluminescence is obtained in volts and converted into light flux in microwatts per square metre. The calibration system detailed in Geistdoerfer and Vincendeaw (1999) uses a reference photomultiplier tube for which the correspondence between voltage and power flux is known. The CTD scanning frequency was set up at $4 \mathrm{~Hz}$ and the descent rate was approximately $1 \mathrm{~m} \mathrm{~s}^{-1}$.

In vivo fluorescence signals given by the Chelsea fluorometer were calibrated using comparison with chlorophyll a measurements on 253 samples. Chlorophyll a concentrations (in milligrams per cubic metre) were determined using a high pressure liquid chromatography technique as used by Vidussi et al. (1996) Accordingly, the relationship used to convert fluorescence values into chlorophyll a (Chl a) is: 

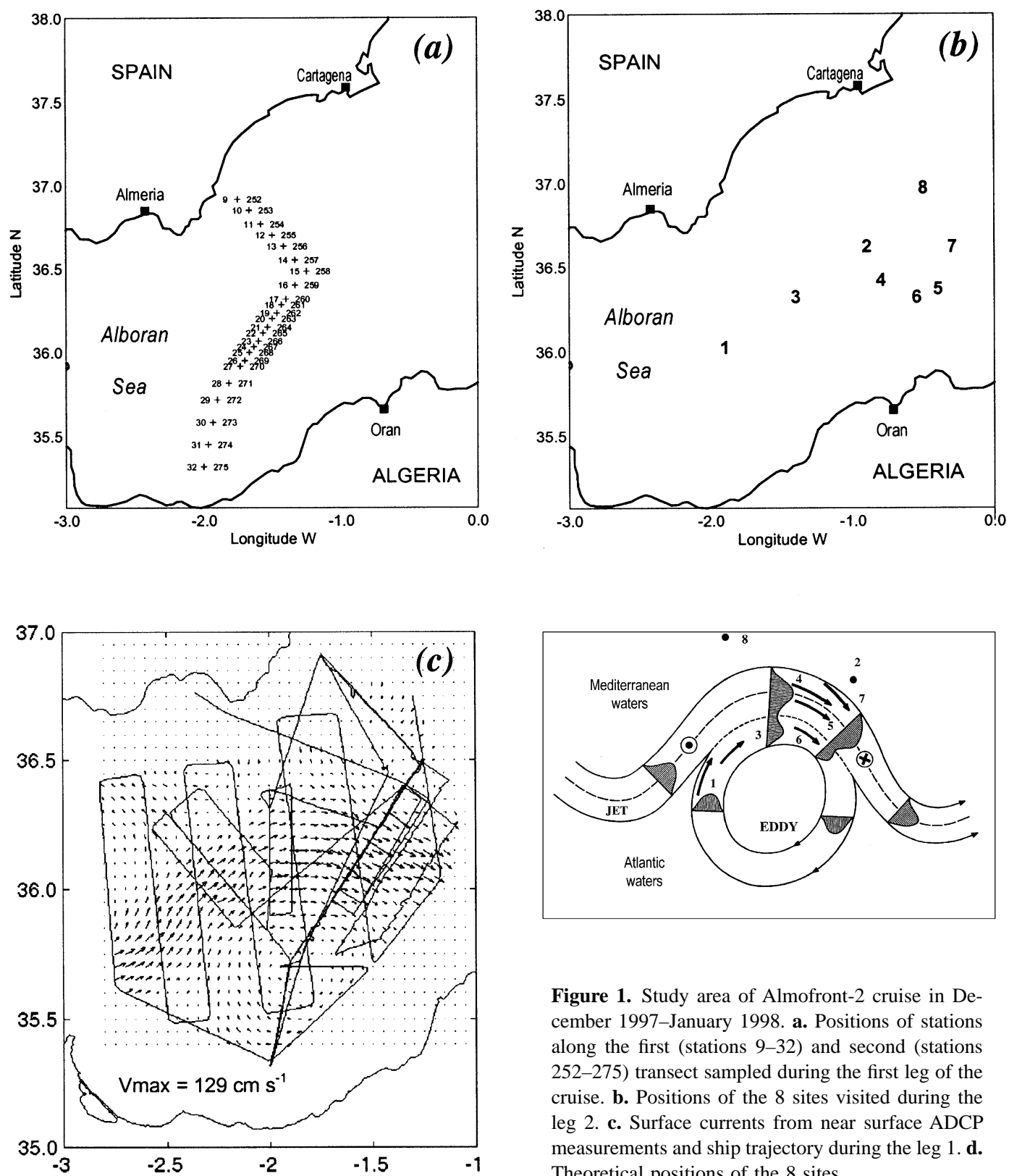

Figure 1. Study area of Almofront-2 cruise in December 1997-January 1998. a. Positions of stations along the first (stations 9-32) and second (stations 252-275) transect sampled during the first leg of the cruise. b. Positions of the 8 sites visited during the leg 2. c. Surface currents from near surface ADCP measurements and ship trajectory during the leg 1 . d. Theoretical positions of the 8 sites.

Chlorophyll $\left(\mathrm{mg} \mathrm{m}^{-3}\right)=1.85$ Fluorescence $(r=0.83)$.

\section{RESULTS}

\subsection{Hydrological description of the area}

The regular sampling along the transect allowed the visualization of the different hydrological areas crossed 


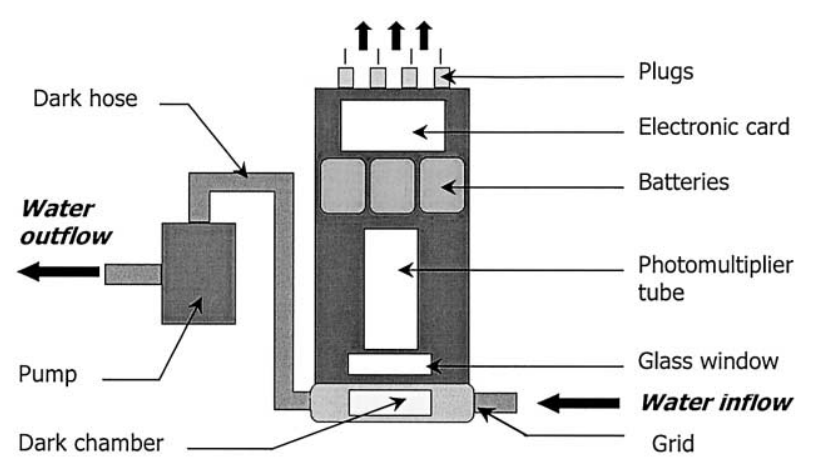

Figure 2. Diagram of the bathyphotometer. A pump with a constant flow rate $\left(0.4 \mathrm{~L} \mathrm{~s}^{-1}\right)$ ensures the incoming seawater flow in the dark chamber. A grid at the entrance of the chamber restricts entry of organisms greater than $1 \mathrm{~mm}$ and provokes a turbulent flow, inducing a mechanical and synchronic stimulation of the organisms entering into the chamber. A glass window separates the dark chamber from a photomultiplier, which can detect light intensities from $10^{-4}$ to $10^{-9} \mu \mathrm{W} \mathrm{cm}{ }^{-2}$.

by the ship. Cold and salty Mediterranean waters in the NE of the Alboran Sea (stations 9-16 and 252-259) are separated from warmer and lower salinity Atlantic water in the SW (stations 21-32 and 264-275) by a frontal zone (stations 17-20 and 260-263) (Prieur and Somrnia 1094a.
From south to north and considering the order 1, 3, 6, 5, $4,7,8,2$, the 8 sites can be viewed as a virtual cross section of the jet. Sites 1,3 and 6 are located in the Atlantic water eddy, site 6 is at the limit between the eddy and the jet. Sites 4 and 5 are in the jet core, site 7 is on the left side of the jet and sites 8 and 2 are in oligotrophic Mediterranean waters (foure 1 d).
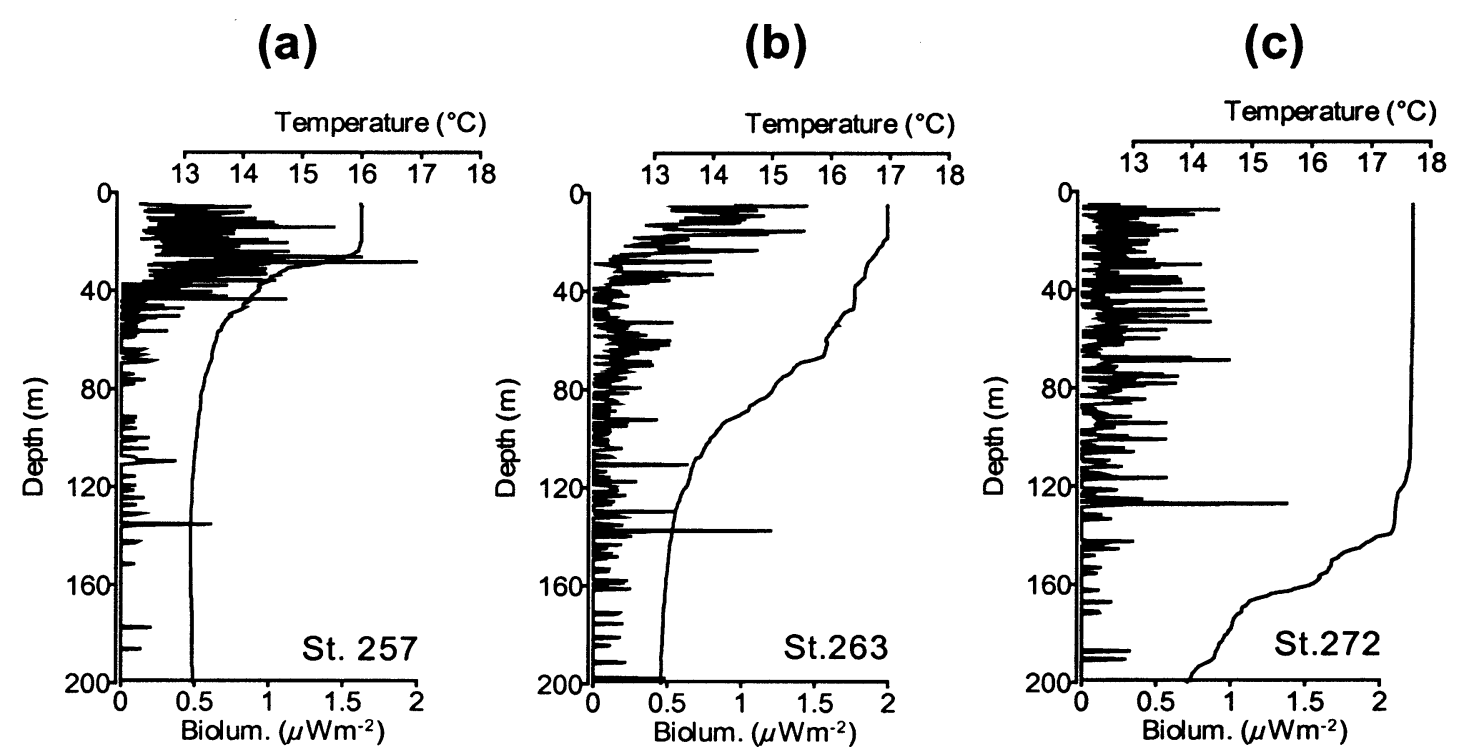

Figure 3. Vertical profiles of bioluminescence and temperature measured in Alboran Sea in december 1997. a. Station 257 located in Mediterranean waters. b. Station 263 in the frontal zone. c. Station 272 in Atlantic waters. 

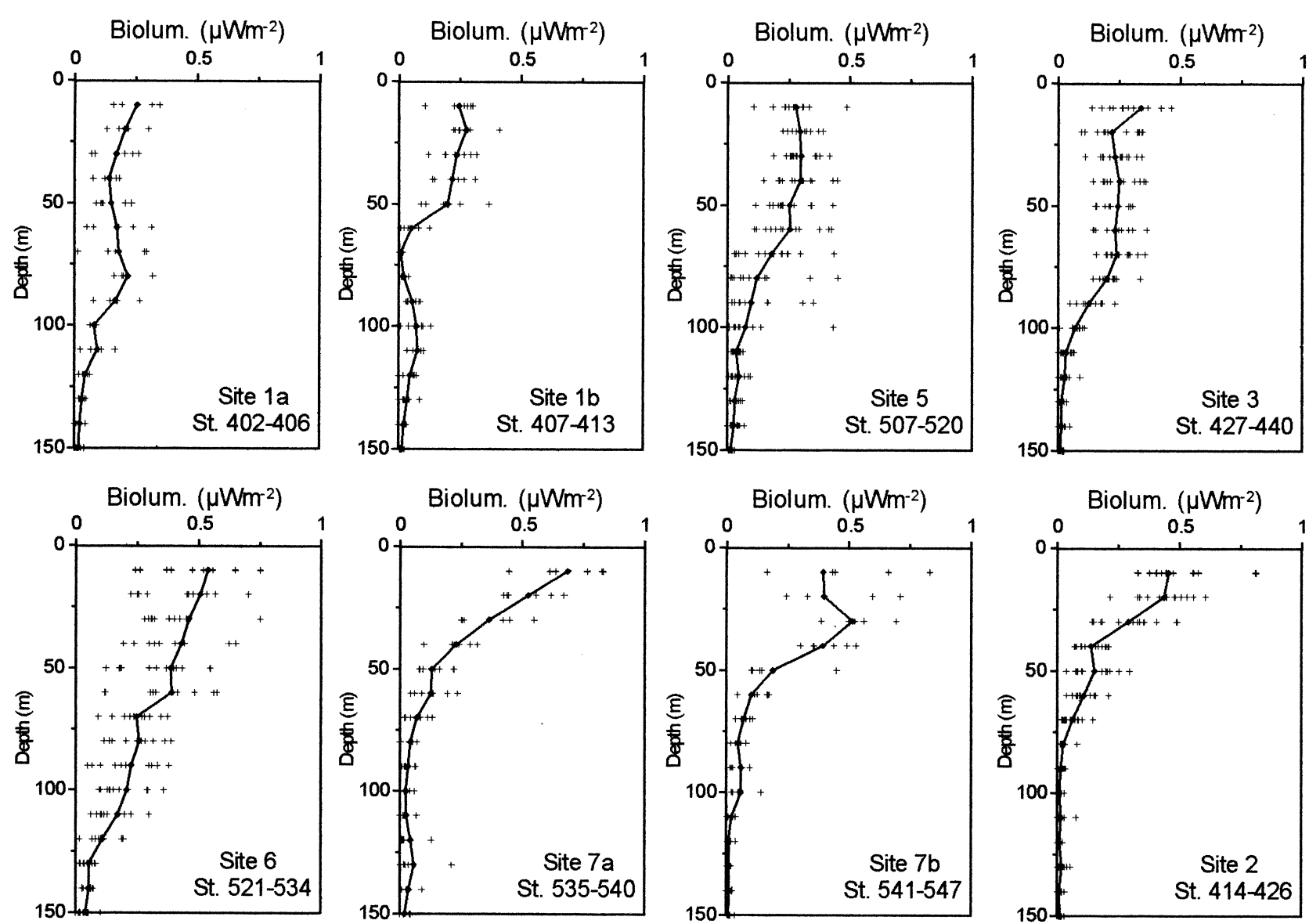

Figure 4. Composite luminescence profiles at selected sites visited during leg 2 .

\subsection{Bioluminescence and fluorescence profiles}

Bioluminescence profiles indicate a strong stratification in Mediterranean waters with very numerous flashes of maximum intensities ranging from 0.6 to $2 \mu \mathrm{W} \mathrm{m} \mathrm{m}^{-2}$ just above the thermocline, around $30 \mathrm{~m}$ (figure $3 \mathrm{~d}$ ). In the southern part of the frontal zone, flash intensities are maximal at the surface (around $1 \mu \mathrm{W} \mathrm{m}^{-2}$ ) and decrease exponentially with depth down to $40 \mathrm{~m}$. Flashes are numerous between $40 \mathrm{~m}$ to $160 \mathrm{~m}$ (fgure $3 \mathrm{~b}$ ). In southern Atlantic waters, bioluminescent flashes are numerous, evenly distributed and of medium intensities $(0.1$ to $1 \mu \mathrm{W} \mathrm{m}^{-2}$ ) in the mixed layer down to $130 \mathrm{~m}$ (figure 3d).

Raw profiles (not shown) indicate that bioluminescence is maximum in the surface layer up to 50-100 m. At these depths, flashes are numerous and of great intensity (from 0.3 to $1.6 \mu \mathrm{W} \mathrm{m}{ }^{-2}$, more than 50 flashes per $10 \mathrm{~m}$ ).
Below this layer up to $250 \mathrm{~m}$, only a few flashes of low intensity are generally recorded (around $0.2 \mu \mathrm{W} \mathrm{m}{ }^{-2}$, $0-5$ flashes per $10 \mathrm{~m}$ ). Beyond $250 \mathrm{~m}$, no more regular luminous events occur and bioluminescence is only represented by some flashes, very scarce but observable up to $2500 \mathrm{~m}$. These deep luminescent events can be surprisingly strong in intensity (up to $2 \mu \mathrm{W} \mathrm{m}{ }^{-2}$ ). 
In order to compare all the profiles, bioluminescence and fluorescence data were depth-binned to $10 \mathrm{~m}$ resolution over a 10 to $150 \mathrm{~m}$ range. Composite profiles for all the stations of a given site show that vertical distribution of bioluminescence is homogeneous inside the same site but varies between sites (foure 4). The same observation is made for fluorescence. For sites 1 and 7, two different types of structure were observed regarding biology as well as hydrology.

As each site may be characterized by bioluminescence and fluorescence profiles, one station per site was chosen to represent the vertical distribution of these parameters of each site. All the stations selected were sampled at around four o'clock in the morning (foure $)$.

The stations of sites 1 are characterized by either a maximum (foure 5d) or a minimum (foure 5b) of bioluminescence and fluorescence around $60-80 \mathrm{~m}$ $\left(0.3 \mu \mathrm{W} \mathrm{m}^{-2}\right.$ and $1.8 \mathrm{mg} \mathrm{m}^{-3} \mathrm{Chl}$ a at site $1 \mathrm{a} ; 0 \mu \mathrm{W} \mathrm{m} \mathrm{m}^{-2}$ and $0.2 \mathrm{mg} \mathrm{m}^{-3} \mathrm{Chl}$ a at site $1 \mathrm{~b}$ ). All profiles of sites 4 and 5 indicate a stratification of biological parameters which both decrease abruptly below $50 \mathrm{~m}$ depth (from 0.3 to $0.05 \mu \mathrm{W} \mathrm{m}{ }^{-2}$ for bioluminescence and from 0.65 to $0.2 \mathrm{mg} \mathrm{m}^{-3} \mathrm{Chl}$ a for fluorescence at site 5 , Ggure $5 \mathrm{c}$ ). Profiles of these 2 sites are very similar although fluorescence is more important at site 4. Fluorescence and bioluminescence at site 3 reach a maximum between 70 and $100 \mathrm{~m}$ (figure 5d). Frontal site (site 6) is remarkable for the irregular profiles where fluorescence and bioluminescence show several maxima at various depths figure 5e). High values of bioluminescence and fluorescence are recorded from the surface to $130 \mathrm{~m}$. Site $7 \mathrm{a}$ and $7 \mathrm{~b}$ are marked by 1 or 2 fluorescence peaks $\left(0.9 \mathrm{mg} \mathrm{m}^{-3} \mathrm{Chl} \mathrm{a}\right)$ in the first $50 \mathrm{~m}$ with no corresponding bioluminescence maxima (Goures 5 fand 5 ). Light emissions reach 0.5 to $0.8 \mu \mathrm{W} \mathrm{m}{ }^{-2}$. At both sites 8 and 2 (Mediterranean waters, Goure 5h), bioluminescence is maximum in the mixed layer (around $0.5 \mu \mathrm{W} \mathrm{m}^{-2}$ ) with a second maximum at the thermocline $(50 \mathrm{~m})$ and it decreases to near $0 \mu \mathrm{W} \mathrm{m} \mathrm{m}^{-2}$ below $70 \mathrm{~m}$. Fluorescence shows a sub-surface maximum between 50 and $80 \mathrm{~m}\left(0.75 \mathrm{mg} \mathrm{m}^{-3} \mathrm{Chl} \mathrm{a}\right)$.

\subsection{Mean bioluminescence}

Because sampling of the cross section was continuous, it involved night and day measurements. Bioluminescence being submitted to nycthemeral variations, comparisons between stations can be made only with ones sampled at similar hours. Taking stations sampled in the same range of hours, mean bioluminescence was calculated from 0 to $150 \mathrm{~m}$. Comparison between the three water masses (Mediterranean, frontal and Atlantic) shows that bioluminescence is higher in the front $\left(0.175 \mu \mathrm{W} \mathrm{m}{ }^{-2}\right)$ than in surrounding waters (respectively 0.148 and $0.131 \mu \mathrm{W} \mathrm{m}^{-2}$ for Mediterranean and Atlantic waters). This frontal increase is a combined result of high surface values and numerous light emissions down to $130 \mathrm{~m}$ depth (goure $3 b)$.

Bioluminescence and fluorescence averaged for each site between 0 and $100 \mathrm{~m}$ are greatest at site 6 where these parameters reach $0.35 \mu \mathrm{W} \mathrm{m}^{-2}$ and $0.85 \mathrm{mg} \mathrm{m}^{-3} \mathrm{Chl} \mathrm{a}$ respectively, and then decrease from both sides of this point (Gigure 6). At all other sites in the Atlantic and in the jet $(1,3,5,4)$, average fluorescence is around $0.6 \mathrm{mg} \mathrm{m}^{-3}$ $\mathrm{Chl} \mathrm{a}$ and reaches minimum values in Mediterranean waters (sites 8 and 2: respectively 0.3 and $0.4 \mathrm{mg} \mathrm{m}^{-3}$ $\mathrm{Chl}$ a). Bioluminescence at sites other than 6 ranges from $0.15-0.23 \mu \mathrm{W} \mathrm{m}{ }^{-2}$.

The ratio of bioluminescence over fluorescence is much higher at site 8 than at other sites, suggesting the presence of non-chlorophyllian bioluminescent organisms.

\subsection{Correlation of bioluminescence vs. fluorescence and temperature}

Bioluminescence and fluorescence profiles suggest that these two parameters have a parallel evolution for sites 1 , 4 and 5, whereas vertical distributions of fluorescence and bioluminescence at other sites are independent. These results are confirmed by the calculation of the correlation coefficient between the two variables table d).

Correlation calculation between bioluminescence and temperature or salinity does not give any significant relationship between these parameters, but the thermocline is in some cases associated with bioluminescence and fluorescence peaks. In Atlantic waters (sites 1, 3 and 6), the thermocline is situated quite deeply at around $100 \mathrm{~m}$ depth, and bioluminescence and fluorescence peaks of medium intensity (sites 3 and 6) or great intensity (site 1a) occur just above it, between 60 and $80 \mathrm{~m}$. No peaks appear inside the jet (4 and 5) but bioluminescence and fluorescence decrease at exactly the same depth as temperature $(50 \mathrm{~m})$. The thermocline in 


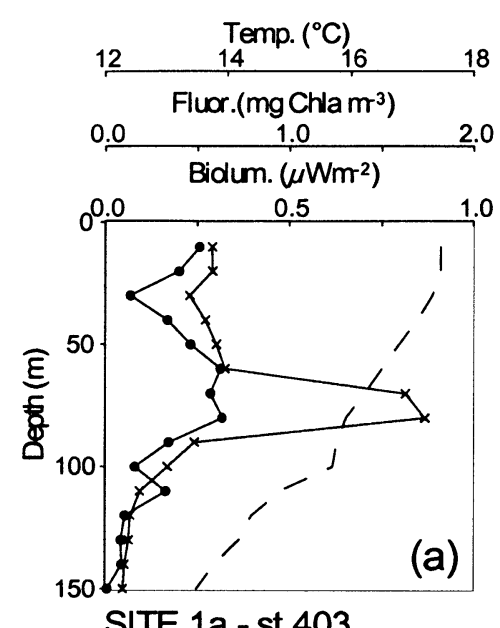

SITE 1a - st 403
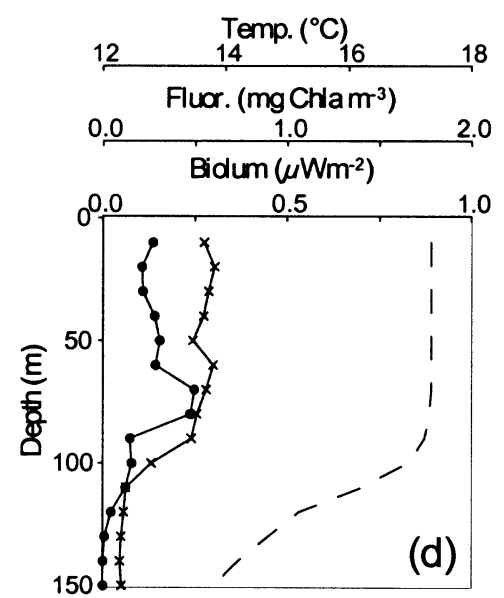

SITE 3 - st 437
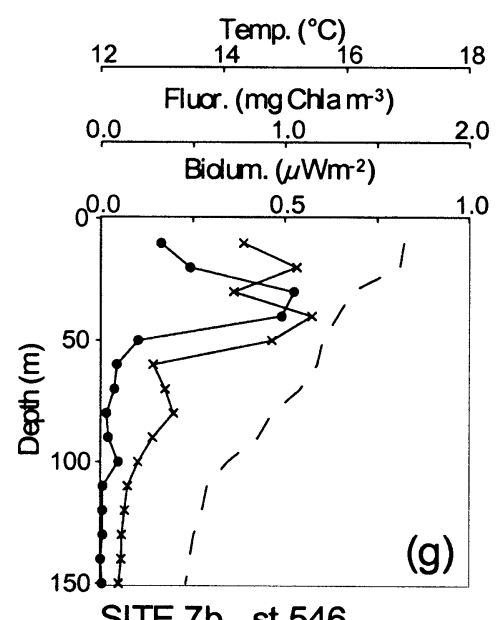

SITE 7b - st 546
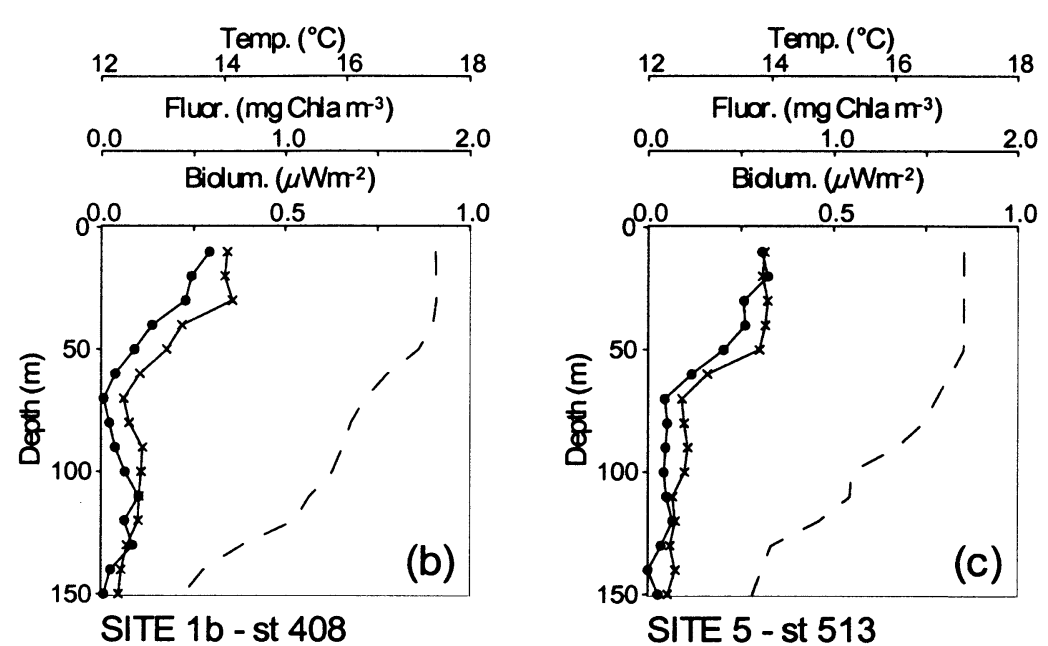

SITE 5 - st 513
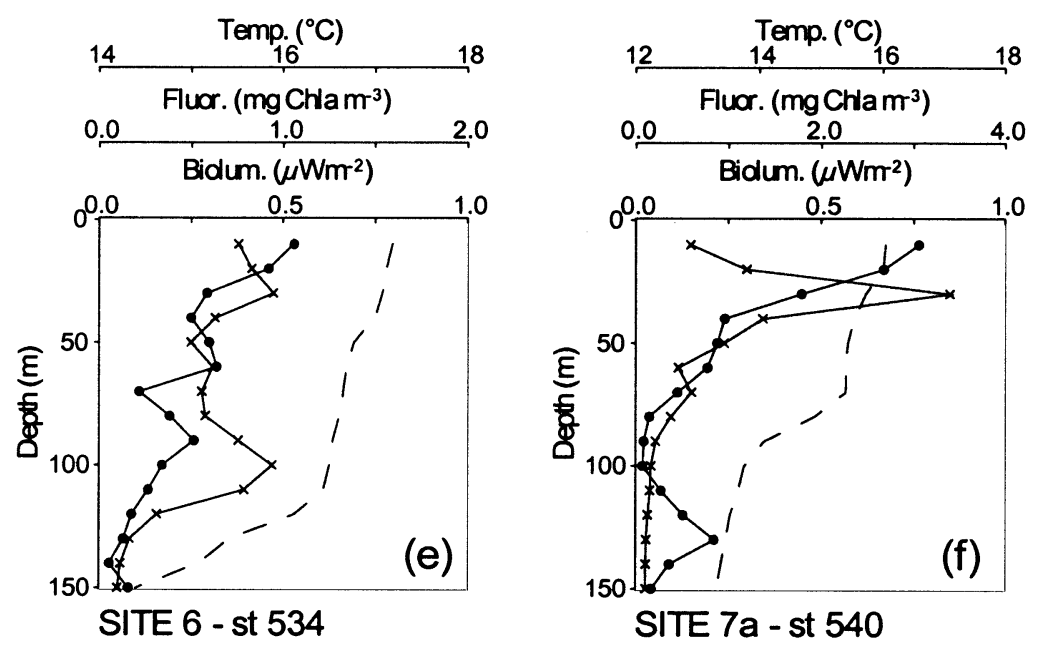

Figure 5. Vertical profiles $(0-150 \mathrm{~m})$ of temperature, bioluminescence and fluorescence at selected sites. Sites 4 and 8 are not represented, as they are respectively similar to sites 5 and 2 . The fluorescence scale of Goure 6 is different, due to strong value of this parameter at this site. 

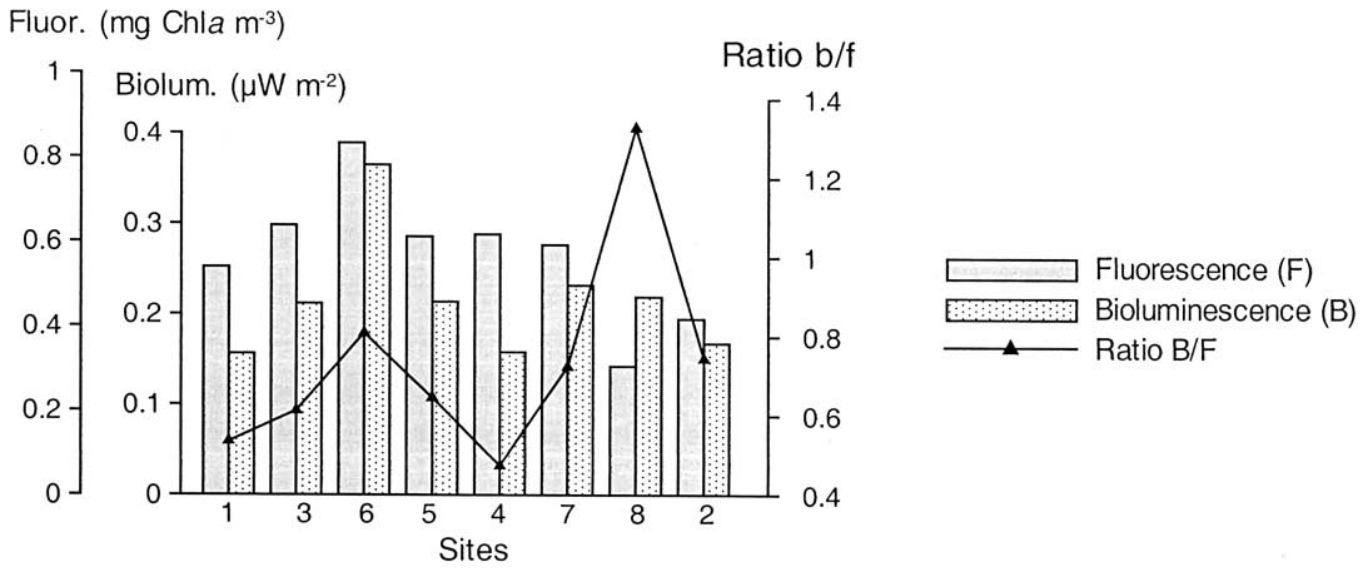

Figure 6. Averaged bioluminescence and fluorescence between 0 and $100 \mathrm{~m}$. Values are maximum at site 6 and decrease from both sides of the front.

Mediterranean waters is at about $50 \mathrm{~m}$ depth and accompanied by a chlorophyll a maximum and a small peak in light emissions.

\subsection{Day and night differences}

For each site, half of the measures were realized at night, so a comparison between night and day bioluminescence was possible. Light emissions in the surface waters $(0-100 \mathrm{~m})$ are always higher at night than during the day (Goure 7). Profile observation shows that light emissions have the same vertical distribution for night and day, night increases correspond to more numerous flashes of greater intensities, it does not correspond to a movement of a deep bioluminescence layer towards the surface at night.

Table I. Correlation analysis for bioluminescence versus fluorescence.

\begin{tabular}{lll}
\hline sites & $r$ & S or NS \\
\hline 1 & 0.69 & S \\
3 & 0.51 & NS \\
6 & 0.25 & NS \\
5 & 0.84 & S \\
4 & 0.86 & S \\
7 & 0.45 & NS \\
8 & 0.14 & NS \\
2 & 0.28 & NS \\
\hline
\end{tabular}

Values are averaged by $10 \mathrm{~m}(n=175$ for each site); $r$ : correlation coefficient; S or NS: significant or non significant correlation.

\section{DISCUSSION}

\subsection{Deep bioluminescent events}

Deep profiles indicate big flashes produced at great depths. The presence of deep bioluminescence has been observed by the first time by American authors Clarke and Kelly 1965) and has since been described in several studies Bradner et al. 1987; Webster et al. 1991). Deep flashes may have several origins, such as the emission of light by dead particles. Andrews et_al_(1984) reported light emission in $70 \%$ of all the collected particles in

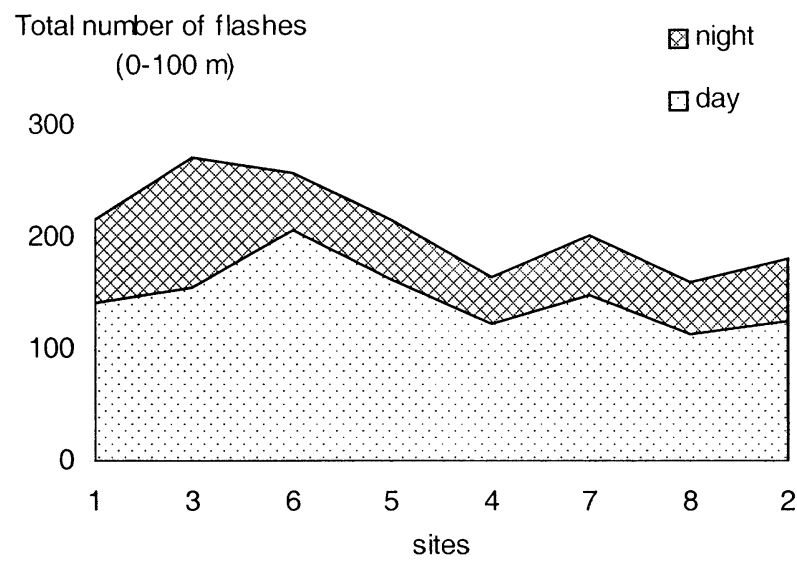

Figure 7. Number of bioluminescence flashes between 0 and $100 \mathrm{~m}$ for each site recorded during the day or during the night. The space between the 2 curves represents the importance of bioluminescence increase at night. 
sediment traps. According to Ruby et al_(1980) bacterial bioluminescence is a very important phenomenon in the total production of light in the oceans. In our case, only small particles can penetrate inside the bathyphotometer so flashes recorded below the euphotic zone could be attributed to copepods, crustacean larvae, or even sinking organic particles inhabited by luminous bacteria. Owing to the fact that deep bioluminescence observed on the profiles is often represented by intense and short flashes, a zooplankton origin of this emitted light is much more probable than a bacterial one which is a continuous glow.

\subsection{Mean bioluminescence in the Alboran Sea}

Averaged values of bioluminescence in the first $100 \mathrm{~m}$ for the whole cruise is $0.22 \mu \mathrm{W} \mathrm{m}{ }^{-2}$. Compared to the Iroise Sea, these values are higher than those observed at the same season $\left(0.05 \mu \mathrm{W} \mathrm{m}{ }^{-2}\right.$ in February 1998) and of the same order than the summer ones $\left(0.28 \mu \mathrm{W} \mathrm{m}{ }^{-2}\right.$ in June and July 1999). The Almeria-Oran frontal zone seems to be indeed particularly rich in bioluminescent organisms. Bitukov et al. (1997) analysed a data bank of 3500 profiles obtained in 25 years over the whole Mediterranean Sea and concluded that light emissions were the greatest in areas where Atlantic and Mediterranean waters interact such as gyres and divergence areas; bioluminescence was found thirty times stronger in the Alboran Sea than in the Black Sea. On a larger scale, bioluminescence has been reported as being higher in upwelling areas Piontkovski et al. 1997) Usually, a very productive area should be rather bioluminescent as a result of primary producers and secondary producers feeding on them as well as senescent cells and faecal pellets rich in bioluminescent bacteria. All these biological compartments are indeed potentially able to produce light.

\subsection{Frontal influence on biological parameters}

Both leg A and B indicated higher chlorophyll content and higher bioluminescence production at the frontal zone than in surrounding waters. The previous mission in May 1991 indicated a chlorophyll maximum in the frontal jet but this increase of primary production was attributed to a growth of diatoms that are not bioluminescent (Claustre et al. 1994; Videau et al., 1994). Observations of enhanced bioluminescence with thermal fronts have been made in the past Lapota_and_Losee, 1984.
Losee et al._1989) In the Gulf of California, enhanced bioluminescence from the warm side to the cold side of the thermal front has been attributed to the presence of increased number of dinoflagellates on the cold side of the front (Lieberman et al. 1987).

Site 6 is characterized by maximum values of bioluminescence and fluorescence over the whole water column. Deep bioluminescence and fluorescence maxima below the euphotic layer reflect the vertical mixing of the water column at this point. A downwelling of biomass as a consequence of a secondary circulation has already been observed in previous studies of the Almeria-Oran frontal zone (Claustre et al. 1994; Videau et al. 1994)

The thermocline is nearly always associated with locally enhanced fluorescence and bioluminescence. Similar situations were mentioned in numerous studies Lapota et al. 1989:- Losee et al. 1985: Swift et al. 1985a.). In our results, there were no bioluminescence peaks associated with thermocline without a fluorescence peak at the same depth. This leads us to the conclusion that organisms responsible for the thermocline bioluminescence increase are chlorophyllian ones, presumably autotrophic dinoflagellates.

\subsection{Relationships between bioluminescence and chlorophyll a}

Bioluminescence being produced by living organisms, places of high biological production are generally rich in bioluminescence. However, light emissions are produced by autotrophic algae, heterotrophic algae or zooplankton and a direct relationship between bioluminescence and chlorophyll is not obvious. Bioluminescence measurements do not allow the recognition of the light producers. However, bioluminescence intensities vary according to plankton categories. Bioluminescence intensity is the weakest in autotrophic dinoflagellates, ten times greater in heterotrophic dinoflagellates and again ten times greater for zooplankton organisms (Swift et al. 1995). Indeed, intense light flashes occurring without fluorescence such as those observed at site 6 and 7 are believed to be due to zooplancton organisms.

Other studies have found a non-systematic correlation between bioluminescence and chlorophyll a fluorescence Losee et al. 1985:_Lapota_et_al._ 1989). In the North Atlantic Ocean, seasonal variations in correlation be- 
tween bioluminescence and fluorescence have been explained by changes in assemblages of organisms (Neilson et al. 1995.

Correlation coefficients are similar for each station at the same site, but great differences between sites clearly reflect the differences in population composition. The good correspondence between bioluminescence and fluorescence profiles at sites 1,4 and 5, with a correspondence of peaks at site 1 and decreases at the same depth for sites 4 and 5, suggests the predominance of bioluminescent chlorophyllian organisms (autotrophic dinoflagellates) at these sites. Inversely, at site 6 where maximum values of average bioluminescence and fluorescence over the whole water column are measured without correspondence of profiles, bioluminescence is produced by a wide variety of organisms. The presence of zooplankton is otherwise confirmed by the mesozooplankton analysis from the plankton sampling, which found the biggest mesozooplankton biomass and abundance at site 6 (R. Gaudy, personal communication). In Mediterranean waters and especially at site 8 , the high luminous activity recorded in poor chlorophyll waters suggest the presence of bioluminescent mesozooplankton or heterotrophic dinoflagellates.

\subsection{Night increase}

Enhanced bioluminescence at night has been frequently observed Batchelder et al. 1992: Buskev et al. 1992) and laboratory experiments have proved that dinoflagel lates are photoinhibited during the day Latz and Lee, 1995: Li et al. 1996) This phenomenon has never been observed in zooplankton organisms. Day to night changes in bioluminescence occur at all sites without any change in the vertical distribution of bioluminescence as it could be observed in case of vertical migration of bioluminescent organisms.

Because the bathyphotometer only measure the light emitted by small organisms, the bigger organisms such as euphausiids are not taken into account. Hence we believe that the increase in bioluminescence at night mainly reflects the presence of dinoflagellates whose bioluminescence ability is photoinhibited during daylight hours. The influence of copepods in the day to night changes of bioluminescence may as well be non-negligible but cannot be estimated in this study.

\section{Acknowledgements}

The Almofront-2 frontal experiment was a part of the programme JGOFS-France funded by INSU. RV l'Atalante is operated by Ifremer. We would like to thank the people who accepted the revision of this paper.

\section{REFERENCES}

Andrews, C.C., Karl, D.M., Small, L.F., Fowler, S.W., 1984. Metabolic activity and bioluminescence of oceanic faecal pellets and sediment trap particles. Nature 307, 539-541.

Batchelder, H.P., Swift, E., Keuren, J.R., 1990. Pattern of planktonic bioluminescence in the northern Sargasso Sea: Seasonal and vertical distribution. Mar. Biol. 104, 153-164.

Batchelder, H.P., Swift, E., Van Keuren, J.R., 1992. Diel patterns of planctonic bioluminescence in the northern Sargasso Sea. Mar. Biol. 113, 329-339.

Bitukov, E.P., Tokarev, Y., Piontkovski, S.A., Vasilenko, V.I., Williams, R., Sokolov, B.G., 1997. The bioluminescence field as an indicator of the spatial structure of the planktonic community of the Mediterranean sea bassin. In: Hastings, J.W., Kricka, L.J., Stanley, P.E. (Eds.), Molecular reporting with photons: 9th international symposium on bioluminescence and chemiluminescence, Woods Hole, MA. John Wiley and Sons, Chichester, pp. 169-171.

Bradner, H., Bartlett, M., Blackinton, G., Clem, J., 1987. Bioluminescence profile in the deep Pacific Ocean. Deep-Sea Res. 34, 1831-1840.

Buskey, E.J., Strom, S., Coulter, C., 1992. Bioluminescence of heterotrophic dinoflagellates from Texas coastal waters. J. Exp. Mar. Biol. Ecol. 159, 37-49.

Chenay, R.E., 1978. Recent observations of the Alboran Sea frontal system. J. Geophys. Res. 83, 4593-4597.

Chenay, R.E., Doblar, R., 1982. Structure and variability of the Alboran Sea frontal system. J. Geophys. Res. 87, 585-594.

Clarke, L., Kelly, M.G., 1965. Measurements of diurnal changes in bioluminescence from the sea surface tometers using a new photometric device. Limnol. Oceanogr. 10, 54-66.

Claustre, H., Kerherve, P., Marty, J.C., Prieur, L., Videau, C., Hecq, J.H., 1994. Phytoplankton dynamics associated with a geostrophic front: ecological and biogeochemical implications. J. Mar. Res. 52, 711-742.

Evstigneev, P.V., Cheripanov, O.V., 1997. The identification of planctonic organisms by their bioluminescent signals. J. Biolum. Chemilum. 12, 41-42.

Geistdoerfer, P., Vincendeau, M.A., 1999. A new bathyphotometer for bioluminescence measurements on the Armorican Continental Shelf (Northeastern Atlantic). Oceanol. Acta. 22, 137-151.

Gould, R.W., Wiesenburg, D.A., 1990. Single-species dominance in a subsurface phytoplancton concentration at a Mediterranean Sea front. Limnol. Oceanogr. 35, 211-220. 
Herring, P.J., 1978. Bioluminescence of Invertebrates other than insects. In: Herring, P.J. (Ed.), Bioluminescence in Action. Academic Press, London, pp. 199-240.

Holligan, P.M., 1981. Biological implications of fronts on the northwest European continental shelf. Phil. Trans. R. Soc. Lond. A302, 547-562.

Lapota, D., Duckworth, D., Paden, S., Groves, J., 1995. Seasonal planktonic bioluminescence in the southern California Bight. In: Hawkins, L.E., Hutchinson, S. (Eds.), 30th European marine biological symposium, Southampton, UK. Southampton Oceanography Centre, Southampton, pp. 79-85.

Lapota, D., Geiger, M.L., Stiffey, A.V., Rosenberger, D.E., Young, D.K., 1989. Correlations of planktonic bioluminescence with other oceanographic parameters from a Norwegian fjord. Mar. Ecol. Prog. Ser. 55, 217-227.

Lapota, D., Losee, J.R., 1984. Observations of bioluminescence in marine plankton from the Sea of Cortez. J. Exp. Mar. Biol. Ecol. 77, 209-240.

Lapota, D., Paulen, S., Duckworth, D., Rosenberg, D.E., Case, J.F., 1994. Coastal and oceanic bioluminescence trends in the Southern California Bight using MOORDEX bathyphotometers. In: Campbell, A.K., Kricka, L.J., Stanley, P.E. (Eds.), Bioluminescence and chemiluminescence: fundamentals and applied aspects. John Wiley and Sons, Chichester, pp. 127-130.

Latz, M.I., Lee, A.O., 1995. Spontaneous and stimulated bioluminescence of the dinoflagellate Ceratocorys Horrida (Peridiniales). J. Phycol. 31, 120-132.

Li, Y., Swift, E., Buskey, E.J., 1996. Photoinhibition of mechanically stimulable bioluminescence in the heterotrophic dinoflagellate Protoperidinium depressum. J. Phycol. 32, 974-982.

Lieberman, S.H., Lapota, D., Losee, J.R., Zirino, A., 1987. Planktonic bioluminescence in the surface waters of the Gulf of California. Biol. Oceanogr. 4, 25-46.

Lohrenz, S.E., Arnone, R.A., Wiesenburg, A., DePalma, I.P., 1988. Satellite detection of transient enhanced primary production in the western Mediterranean Sea. Nature 335, 245-247.

Lohrenz, S.E., Denis, A., Wiesenburg, A., DePalma, I.P., Kenneth, S.J., Gustafson, D.E., 1988. Interrelationships among primary production, chlorophyll, and environmental conditions in frontal regions of the western Mediterranean Sea. Deep-Sea Res. 35, 793-810.

Losee, J., Lapota, D., Lieberman, S.H., 1985. Bioluminescence: a new tool for oceanography. Adv. Chem. Ser. 209, 211-234.

Losee, J., Richter, K., Lieberman, S., Lapota, D., 1989. Bioluminescence: spatial statistics in the North Atlantic. Deep-Sea Res. 36, 783-801.

Neilson, D.J., Latz, M.I., Case, J.F., 1995. Temporal variability in the vertical structure of bioluminescence in the North Atlantic Ocean. J. Geophys. Res. 100, 6591-6603.

Pingree, R.D., Pugh, P.R., Holligan, P.M., Forster, G.R., 1975. Summer phytoplankton blooms and red-tides along tidal fronts in the approaches to the English Channel. Nature 258, 672-677.
Piontkovski, S.A., Tokarev, Y.N., Bitukov, E.P., Williams, R., Kiefer, D.A., 1997. The bioluminescent field of the Atlantic Ocean. Mar. Ecol. Prog. Ser. 156, 33-41.

Prieur, L., Copin-Montégut, C., Claustre, H., 1993. Biophysical aspects of 'Almofront-1', an intensive study of a geostrophic frontal jet. Ann. Inst. Océanogr. 69, 71-86.

Prieur, L., Sournia, A., 1994a. Processes and fluxes in the the Geostrophic America-Oran Front. J. Mar. Systems 5, 187-399.

Prieur, L., Sournia, A., 1994b. Almofront-1 (April-May1991): an interdisciplinary study of the Almeria-Oran geostrophic front, SW Meditrranean Sea. J. Mar. Systems 5, 187-203.

Ruby, E.G., Greenberg, E.P., Hastings, J.W., 1980. Planktonic marine luminous bacteria: species distribution in the water column. Appl. Environ. Microbiol. 39, 302-306.

Sournia, A., Brylinski, J.M., Dallot, S., Corre, P.L., Leveau, M., Prieur, L., Froget, C., 1990. Fronts hydrologiques au large des côtes françaises : les sites ateliers du programme Frontal, Oceanol. Acta. 13, 413-438.

Swift, E., Biggley, W.H., Verity, P.G., Brown, D.T., 1983. Zooplankton are major sources of epipelagic bioluminescence in the southern Sargasso Sea. Bull. Mar. Sci. 33, 855-863.

Swift, E., Biggley, W.H., Lessard, E.J., 1985. Distributions of epipelagic bioluminescence in the Sargasso and Caribbean Seas. Adv. Chem. Ser. 209, 235-258.

Swift, E., Lessard, E.J., Biggley, W.H., 1985. Organisms associated with epipelagic bioluminescence in the Sargasso and the Gulf Stream. J. Plank. Res. 7, 831-848.

Swift, E., Sullivan, J.M., Batchelder, H.P., Van Keuren, J., Vaillancourt, R.D., Bidigare, R.R., 1995. Bioluminescent organisms and bioluminescence measurements in the North Atlantic Ocean near latitude $59.5^{\circ} \mathrm{N}$, longitude $21^{\circ} \mathrm{W}$. J. Geophys. Res. 100, $6527-6547$.

Tett, P.B., Kelly, M.G., 1973. Marine bioluminescence. Oceanogr. Mar. Biol. Annu. Rev. 11, 89-173.

Tintoré, J., La Violette, P.E., Blade, I., Cruzado, A., 1988. A study of an intense density front in the eastern Alboran Sea: The Almeria-Oran front. J. Phys. Oceanogr. 18, 1384-1397.

Videau, C., Sournia, A., Prieur, L., Fiala, M., 1994. Phytoplankton and primary production characteristics at selected sites in the geostrophic Almeria-Oran front system (SW Mediterranean Sea). J. Mar. Sys. 5, 235-250.

Vidussi, F.H., Claustre, J., Bustillos-Guzmàn, C., Cailleau, C., Marty, J.C., 1996. Rapid HPLC determination of phytoplankton chemotaxinomic pigments: Separation of chlorophyll a from divinylchlorophyll a and zeaxanthin from lutein. J. Plankton Res. 18, 2377-2382.

Webster, M.S., Roos, C.E., Roberts, A., Okada, A.O.Y., O'Connor, D.M.R., Matsuno, S., March, R., 1991. Mechanical stimulation of bioluminescence in the deep Pacific Ocean. Deep-Sea Res. 38, 201-217. 